\title{
Partai Politik Sebagai Political Brand
}

\author{
Fajar Febriansyah", Guntur Freddy Prisanto $^{2}$, Niken Febrina Ernungtyas ${ }^{3}$, Safira Hasna ${ }^{4}$ \\ 1,2,3,4 STIKOM Interstudi, Jakarta, Indonesia \\ e-mail: fajardpr@gmail.com
}

Cara Sitasi: Fajar F, Guntur F P, Niken F E, Safira H (2021) Partai Politik Sebagai Political Brand, 2021 21(1), 68- 73 Retrieved from https://doi.org/10.31294/jc.v19i2

\begin{abstract}
Nowadays, political parties need a political marketing strategy that is considered to be able to increase the number of votes, especially for certain candidates of political parties. Marketing elements can be adopted in political parties, especially when doing branding. Therefore, the objective of this research is to determine the influence of brand elements in politics such as brand communication, brand image, brand trust, and brand loyalty to political parties, namely Partai Amanat Nasional (PAN). The research shows that there is no effect of brand communication on brand image and brand trust. And there is no influence of brand image on brand trust. As for the element of trust, there is an effect of brand trust on PAN brand loyalty with a low percentage of 14.7\%. When someone has given confidence in a certain political party, they have guaranteed that the program given by that party is the best for the public, so that someone will be consistent in choosing the same party in the future during the election or loyal to political parties.
\end{abstract}

Keywords: Brand Communication, Brand Image, Brand Trust, Brand Loyalty, Political Party

\section{PENDAHULUAN}

Partai politik sebagai salah satu media yang digunakan untuk menampung aspirasi rakyat, menjadi komponen utama penting dalam rangka mendongkrak pemilih pada pesta demokrasi di Indonesia. Budiarjo (2010) mengatakan partai politik merupakan salah satu kelompok terorganisir yang anggotanya memiliki orientasi dan tujuan yang sama, dimana tujuan kelompok ini untuk mendapatkan kekuasaan politik dan merebut kedudukan politik dengan cara konstitusional untuk melaksanakan kebijakan-kebijakan mereka.

Tujuan utama dari partai politik tersebut adalah untuk mendapatkan kedudukan atau kekuasaan politik di suatu negara dengan menggunakan cara-cara yang bersifat konsititusional. Partai politik memiliki empat fungsi utama meliputi: (1) Media komunikasi, terutama media komunikasi dari pemerintah kepada rakyat, dana atau juga rakyat kepada pemerintah. Partai politik difungsikan sebagai penyerap aspirasi masyarakat dan mengumpulkan informasi dan meneruskannya kepada pemerintah; (2) Media Sosialisasi, sosialisasi ini sebagai bentuk promosi bagi partai politik terhadap masyarakat agar nantinya mau memilih partai tersebut. Sosialisasi yang baik akan semakin memungkinkan masyarakat untuk menyukai dan memilih partai politik tersebut; (3) Media Perekrutan, dalam hal ini partai politik sebagai lembaga penyeleksi sekelompok orang ataupun orang secara pribadi untuk dibentuk menjadi seorang pemimpin. Orang-orang yang direkrut dan dibina oleh partai inilah yang nantinya diharapkan dapat menjadi seorang pemimpin yang kompeten; (4) Media Pencegah Konflik, partai politik harus mampu menjadi penampung perbedaan pendapat ataupun persoalan lainnya dengan cara berdialog. Cara-cara seperti ini sebagai salah satu fungsi partai politik untuk menemukan keputusan politik yang paling tepat untuk menyelesaikan sebuah masalah (Darmawan \& Septiana, 2019).

Untuk mencapai fungsinya tersebut, partai politik membutuhkan strategi pemasaran politik yang dinilai dapat meningkatkan jumlah suara khususnya bagi kader partai politik tertentu. Pemasaran politik dilakukan karena pilihan yang dibuat oleh pemilih pada saat pemilihan dapat dianalogikan dengan pilihan yang dibuat konsumen antara produk atau layanan komersial. Kemudian ada kesamaan antara pemasaran produk atau layanan konsumen yang mempromosikan barang tetapi dalam hal politik, mempromosikan partai politik. Jika kampanye politik dalam jangka pendek dirancang untuk mempengaruhi target tertentu dan terbatas pada periode waktu tertentu (pemilu dan pemilih), saat ini dapat digantikan dengan pemasaran politik sebagai aktivitas jangka panjang yang bertujuan untuk meningkatkan "merek" dari partai politik. Oleh 
karena itu, elemen-elemen brand penting dalam pemasaran politik seperti brand communication, brand image, brand trust dan brand loyalty dapat menjadi elemen penting dalam pemasaran politik.

Pada sektor komersil, brand dinilai dapat menghasilkan banyak keuntungan. Merek adalah kunci utama dalam pemasaran terintegrasi, mengingat merek merupakan inti atau pusat dari apa yang diinginkan, dibutuhkan, dan dianggap oleh konsumen sebagai nilai. Brand merupakan representasi dari identitas suatu organisasi atau objek yang menjadi identitas sehingga dapat menjadi representasi dari suatu organisasi tersebut. Brand dalam konteks politik dapat berupa partai politik yang bisa menargetkan persepsi, sikap, dan perilaku pemilih sehingga dapat membangun hubungan yang konkrit dengan pemilihnya (Abdelbaset M. Alkhawaldeh, Bt, \& Halim, 2016). Oleh karena itu, merek membutuhkan komunikasi atau brand communication. Hal ini menjadi penting untuk mengekspos audiens ke suatu merek dimana efeknya dapat dimaksimalkan dengan meningkatkan kesadaran dan daya ingat yang lebih tinggi sehingga setiap eksposur terhadap komunikasi dapat mempengaruhi respon konsumennya. Dalam hal ini, brand communication dapat meningkatkan loyalitas merek dengan cara membuat konsumen lebih terikat pada suatu merek untuk memperkuat hubungan merek konsumen dari waktu ke waktu (Zehir, Şahin, Kitapçi, \& Özçahin, 2011).

Partai Amanat Nasional (PAN), salah satu partai di Indonesia yang lahir pada masa reformasi yang memiliki kader dan anggota dewan di tingkat pusat (DPR RI) dan anggota dewan di tingkat daerah (DPRD) serta memiliki perwakilan di tingkat menteri pada beberapa periode. Oleh karena itu Partai Amanat Nasional memiliki loyalitas pada basis kader yang kuat. Dapat dikatakan loyalitas dari suatu merek, sikap yang mutlak dan menjadi fundamental dalam ranah organisasi, bahkan sikap tersebut menuntun seseorang untuk menemukan sosok kader yang memiliki integritas, jujur serta memiliki karakter yang kuat sehingga sikap tersebut harus ditumbuh kembangkan dalam organisasi khususnya dalam penelitian ini yaitu Partai Amanat Nasional.

Dalam membangun loyalitas yang tinggi kader diperlukan suatu proses panjang dari internal partai. Membangun komunikasi yang efektif di dalam internal PAN merupakan salah satu cara mengembangkan partai serta diharapkan meningkatkan loyalitas kader karena didalamnya terdapat keterbukaan aliran informasi dari atas kebawah atau komunikasi diantara kader partai terjalin dengan baik.

Namun demikian berdasarkan hasil perhitungan suara legislatif secara nasional Partai Amanat Nasional (PAN) mengalami fluktuasi, yaitu pada Pemilu tahun 2004 sebesar 7.303.324 (6,44\%), tahun 2009 sebesar $6.254 .580(6,01 \%)$, tahun 2014 sebesar 9.481.621 (7,59\%), serta di tahun 2019 sebesar 9.572.623 (6,84\%) (kpu.go.id). Melihat data tersebut dapat dikatakan bahwa Partai Amanat Nasional belum dapat secara konsisten menjalankan strategi-strategi pemasaran partai yang pada tingkat loyalitas pemilih dengan mengedepankan kepercayaan yang diberikan oleh masyarakat.

Brand communication atau komunikasi merek dapat dikatakan salah satu usaha yang bisa dilakukan oleh Partai Amanat Nasional untuk mengkomunikasikan keunikan yang dimiliknya kepada masyarakat luas atau pemilih. Menurut Kotler dan Armstrong (2016) penyampaian pesan komunikasi setikdaknya harus memperhatikan empat hal yaitu: (1) isi pesan terkait apa yang akan disampaikan; (2) pesan yang disampaikan terstruktur atau bagaimana menyampaikan pesan secara logis; (3) bagaimana menyampaikan pesan dengan simbolsimbol atau bentuk dari pesan yang akan disampaikan; (4) terkait siapa yang menyampaikan pesan tersebut (sumber pesan).

Selain brand communication untuk meningkatkan loyalitas dan kepercayaan dari suatu brand, pemilih Partai Amanat Nasional memiliki brand image yang telah dikenal sebagai partai reformasi, yang tercermin pada prinsip dasar partai yaitu: Partai Amanat Nasional merupakan partai politik yang memperjuangkan kedaulatan rakyat, demokrasi, kemajuan dan keadilan sosial, cita-cita ini berakar pada moral agama, kemanusiaan dan kemajemukan, serta Partai Amanat Nasional sebagai partai reformis akan bersaing dengan partai-partai lain secara terbuka, adil dan jujur untuk mendukung rakyat. Namun demikian bila dilihat hasil Pemilu dari periode ke periode menunjukkan hasil yang fluktuatif. Hal ini dapat dikarenakan tingkat kepercayaan partai yang instabil dari masyarakat sehingga loyalitas para pemilih partai ini pun rendah.

Beberapa penelitian membahas mengenai pentingnya brand communication, brand image, brand trust dan brand loyalty serta pengaruh diantara keempatnya. Sumbal Arif, et al. (2017) dalam penelitiannya menemukan bahwa komunikasi merek melalui media sosial dapat meningkatkan brand image, dimana media sosial merupakan medium yang melibatkan konsumer dan organisasi terasosiasi bersama. Organisasi menyebarkan informasi dan mempengaruhi pelanggan melalui jejaring sosial untuk memeriksa bagaimana tanggapan dari target audiens. Karena media yang digunakan adalah media sosial, cakupan komunikasinya dipastikan akan luas. Komunikasi media sosial langsung menyentuh citra merek karena ketika perusahaan akan mempublikasikan kualitasnya produk dan membedakannya dari pesaingnya maka citra merek akan dikembangkan, sehingga audiens kenal yakin dengan merek yang dikomunikasikan (Arif, Bhatti, Mariam, \& Sadiq, 2018).

Penelitian kedua menemukan bahwa terdapat pengaruh brand communication terhadap brand trust pada pemilih tetap Partai Gerindra saat Pemilu 2019. 
Dengan adanya kemampuan komunikasi merek yang diberikan kepada para pemilih, menimbulkan kepercayaan mereka terhadap anggota dewan terpilih Partai Gerindra yang membuat pemilih mempercayai anggota dewan tersebut akan memberikan kinerja yang positif ketika terpilih menjadi anggota legislatif (Arenggoasih, 2017) .

Penelitian ketiga menyebutkan bahwa brand trust merupakan salah satu elemen yang paling signifikan, karena kepercayaan merupakan kunci dari membangun hubungan dengan orang lain. Keller (2003) menganggap kepercayaan dapat membangun atau menghancurkan hubungan antara dua pihak atau lebih. Kepercayaan ini akan membuat seseorang tertarik untuk memilih anggota maupun partai politik dalam suatu pemilihan umum (Abdelbaset $\mathrm{M}$. Alkhawaldeh, Bt, \& Halim, 2016).

Kebaruan dari penelitian ini adalah ingin menganalisis bagaimana elemen-elemen pemasaran politik brand communication, brand image, brand trust, dan loyalty saling berpengaruh satu sama lain untuk menarik pemilih kepada kandidat dari suatu partai politik. Oleh karena itu muncul beberapa pertanyaan penelitian:

1. Apakah brand communication berpengaruh terhadap brand image Partai Amanat Nasional (PAN)?

2. Apakah brand communication berpengaruh terhadap brand trust Partai Amanat Nasional (PAN)?

3. Apakah brand image berpengaruh terhadap brand trust Partai Amanat Nasional (PAN)?

4. Apakah brand trust berpengaruh terhadap brand loyalty Partai Amanat Nasional (PAN)?

\section{METODOLOGI PENELITIAN}

Penelitian ini menggunakan metode kuantitatif, yang akan menjelaskan pengaruh brand communication dan brand image terhadap brand loyalty dengan brand trust sebagai variabel mediasi. Metode kuantitatif menekankan pada beberapa variabel dengan tujuan menguji teori dan menegakkan fakta-fakta. Ketika mengukur, peneliti menghubungkan konsep yang tak terlihat, ide, atau menyusun pikiran dengan teknik, proses, atau prosedur yang dipakai untuk mengamati ide dalam dunia empiris dengan menekankan dua proses: konseptualisasi dan operasionalisasi (Neuman, 2014). Peneliti menggunakan survey untuk mengumpulkan data, dimana populasi dalam penelitian ini adalah: 1) pria dan wanita, 2) mengetahui kader Partai Amanat Nasional (PAN), 3) melakukan pemilihan Pilihan Legislatif dilanjutkan dengan Pemilihan Presiden. Pengambilan sampel dilakukan dengan teknik simple random sampling, dimana seluruh populasi memiliki probabilitas yang sama untuk dipilih menjadi sampel (Taherdoost, 2018). Sampel pada penelitian ini adalah 30 orang pemilih.

Berikut model penelitian yang dilakukan.

Bagan 1. Model Penelitian

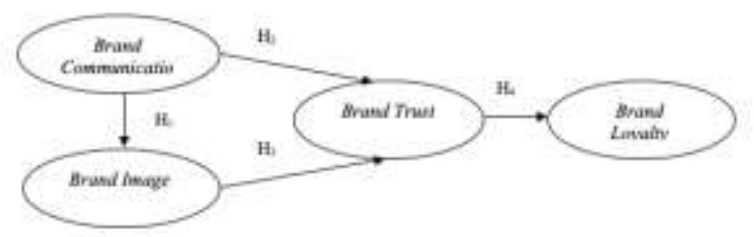

Pada penelitian ini, terdapat empat hipotesis yang akan diuji, yaitu:

H1: Terdapat pengaruh brand communication terhadap brand image Partai Amanat Nasional (PAN) $\mathrm{H} 2$ : Terdapat pengaruh brand communication terhadap brand trust Partai Amanat Nasional (PAN) H3: Terdapat pengaruh brand image terhadap brand trust Partai Amanat Nasional (PAN)

H4: Terdapat pengaruh brand trust terhadap brand loyalty Partai Amanat Nasional (PAN)

\section{OPERASIONALISASI KONSEP}

Tabel 1 Operasionalisasi Variabel Brand Communication

\begin{tabular}{|c|c|c|}
\hline Variabel & Indikator & Operasional \\
\hline \multirow[t]{6}{*}{$\begin{array}{l}\text { Brand } \\
\text { communic } \\
\text { ation }\end{array}$} & \multirow{6}{*}{$\begin{array}{l}\text { ketika ide dari } \\
\text { suatu } \\
\text { program } \\
\text { dipromosikan } \\
\text {, ada suatu ciri } \\
\text { teridentifikasi } \\
\text { diidentifikasi } \\
\text { dan diakui } \\
\text { oleh } \\
\text { masyarakat } \\
\text { atau calon } \\
\text { Kader. }\end{array}$} & $\begin{array}{l}\text { 1. Saya merespon } \\
\text { positif program } \\
\text { yang dilakukan } \\
\text { PAN. }\end{array}$ \\
\hline & & $\begin{array}{l}\text { 2. Saya merasa } \\
\text { program yang } \\
\text { dilakukan PAN } \\
\text { memiliki } \\
\text { pengaruh yang } \\
\text { positif. }\end{array}$ \\
\hline & & $\begin{array}{l}\text { 3. Bentuk prgram } \\
\text { dari PAN } \\
\text { menarik. }\end{array}$ \\
\hline & & $\begin{array}{l}\text { 4. Pesan informasi } \\
\text { dari program } \\
\text { yang dilakukan } \\
\text { PAN } \\
\text { tersampaikan } \\
\text { dengan baik } \\
\text { dibenak } \\
\text { masyarakat. }\end{array}$ \\
\hline & & $\begin{array}{l}\text { 5. Saya senang } \\
\text { pada program } \\
\text { yang dilakukan } \\
\text { PAN. }\end{array}$ \\
\hline & & $\begin{array}{l}\text { 6. Saya menyukai } \\
\text { program yang } \\
\text { dilakukan PAN. }\end{array}$ \\
\hline
\end{tabular}


Tabel 2 Operasionalisasi Variabel Brand Image

\begin{tabular}{|c|c|c|}
\hline Variabel & Indikator & Operasional \\
\hline \multirow[t]{7}{*}{$\begin{array}{l}\text { Brand } \\
\text { image }\end{array}$} & \multirow{7}{*}{$\begin{array}{l}\text { suatu } \\
\text { produk } \\
\text { maupun } \\
\text { jasa dari } \\
\text { sebuah } \\
\text { brand } \\
\text { memiliki } \\
\text { kualitas } \\
\text { yang bagus. }\end{array}$} & $\begin{array}{l}\text { 1. Program yang } \\
\text { ditawarkan PAN } \\
\text { memiliki kualitas } \\
\text { terbaik. }\end{array}$ \\
\hline & & $\begin{array}{ll}\text { 2. } & \text { Program yang } \\
\text { ditawarkan dari } \\
\text { PAN memiliki } \\
\text { karakteristik yang } \\
\text { lebih baik } \\
\text { daripada pesaing. }\end{array}$ \\
\hline & & $\begin{array}{ll}\text { 3. } & \text { Program yang } \\
\text { ditawarkan dari } \\
\text { PAN lebih efektif } \\
\text { dari pesaingnya. }\end{array}$ \\
\hline & & $\begin{array}{l}\text { 4. PAN memiliki } \\
\text { citra yang baik. }\end{array}$ \\
\hline & & $\begin{array}{l}\text { 5. PAN tidak akan } \\
\text { mengecewakan } \\
\text { masyarakat. }\end{array}$ \\
\hline & & $\begin{array}{l}\text { 6. } \\
\text { PAN termaksud } \\
\text { salah satu brand } \\
\text { terbaik di antara } \\
\text { banyak partai. }\end{array}$ \\
\hline & & $\begin{array}{l}\text { 7. PAN sudah di } \\
\text { akui } \\
\text { keberadaanya di } \\
\text { mata masyarakat. }\end{array}$ \\
\hline
\end{tabular}

Tabel 3. Operasionalisasi Konsep Variabel Brand Trust

\begin{tabular}{|c|l|ll|}
\hline Variabel & Indikator & \multicolumn{2}{|c|}{ Operasional } \\
\hline Brand trust & $\begin{array}{l}\text { bahwa } \\
\text { seseorang } \\
\text { percaya akan } \\
\text { brand } \\
\text { tersebut. }\end{array}$ & $\begin{array}{l}\text { PAN dapat } \\
\text { dipercaya. }\end{array}$ \\
\cline { 3 - 4 } & & $\begin{array}{l}\text { 2. } \\
\text { PAN dapat } \\
\text { diandalkan. }\end{array}$ \\
\cline { 3 - 3 } & 3. & PAN amanah. \\
\cline { 3 - 4 } & & $\begin{array}{l}\text { PAN } \\
\text { menjamin } \\
\text { program yang } \\
\text { diberikan } \\
\text { terbaik untuk } \\
\text { masyarakat. }\end{array}$ \\
\hline
\end{tabular}

Tabel 4. Operasionalisasi Konsep Variabel Brand Loyalty

\begin{tabular}{|c|c|c|}
\hline Variabel & Indikator & Operasional \\
\hline \multirow[t]{2}{*}{$\begin{array}{l}\text { Brand } \\
\text { loyalty }\end{array}$} & \multirow{2}{*}{\begin{tabular}{lr}
\multicolumn{2}{l}{ Seseorang } \\
dikatakan & loyal \\
pada & sebuah \\
brand, & maka \\
orang & tersebut \\
akan & kosisten \\
menggunakan
\end{tabular}} & $\begin{array}{l}\text { 1. Saya akan } \\
\text { tetap memilih } \\
\text { PAN. }\end{array}$ \\
\hline & & $\begin{array}{l}\text { 2. Saya tidak } \\
\text { akan berpindah } \\
\text { pada partai } \\
\text { lain. }\end{array}$ \\
\hline
\end{tabular}

\begin{tabular}{|c|c|c|}
\hline Variabel & Indikator & Operasional \\
\hline & $\begin{array}{l}\text { brand yang } \\
\text { sama. }\end{array}$ & $\begin{array}{l}\text { 3. Saya tetap } \\
\text { berkomitmen } \\
\text { pada PAN. }\end{array}$ \\
\hline & & $\begin{array}{l}\text { 4. Saya siap } \\
\text { menanggung } \\
\text { resiko atas } \\
\text { keputusan } \\
\text { untuk memilih } \\
\text { PAN. }\end{array}$ \\
\hline
\end{tabular}

\section{HASIL DAN PEMBAHASAN}

Penelitian mengumpulkan responden $(\mathrm{N}=30)$ yang terdiri dari perempuan $(30 \%)$ dan lakilaki $(70 \%)$. Seluruh responden mengisi kuesioner yang dibagi menjadi empat variabel yaitu (1) brand communication, (2) brand image, (3) brand trust, dan (4) brand loyalty. Masing-masing diukur dengan skala likert. Langkah pertama yang dilakukan adalah pengujian validitas dan reliabilitas. Validitas dilakukan dengan melihat butir instrumen pertanyaan. Dan untuk menguji reliabilitas, alpha croanbachnya harus lebih dari 0,6.

Tabel 5. Uji Reliabilitas

\begin{tabular}{|l|l|l|}
\hline Variabel & $\boldsymbol{\alpha}$ & Keterangan \\
\hline Brand communication & 0,864 & $\begin{array}{l}\text { Valid dan } \\
\text { reliabel }\end{array}$ \\
\hline Brand image & 0,893 & $\begin{array}{l}\text { Valid dan } \\
\text { reliabel }\end{array}$ \\
\hline Brand trust & 0,740 & $\begin{array}{l}\text { Valid dan } \\
\text { reliabel }\end{array}$ \\
\hline Brand loyalty & 0,807 & $\begin{array}{l}\text { Valid dan } \\
\text { reliabel }\end{array}$ \\
\hline
\end{tabular}

Sumber: olahan SPSS

Hasil uji reliabilitas pada variabel penelitian ini dapat dikatakan reliabel karena nilai alpha croanbachnya $>0,6$.

Selanjutnya peneliti menggunakan uji regresi linear untuk mengetahui seberapa besar pengaruh brand communication dan brand image terhadap brand loyalty dengan brand trust sebagai variabel mediasi.

Tabel 6. Nilai R Square

\begin{tabular}{|l|l|l|}
\hline \multicolumn{1}{|c|}{ Variabel } & R Square & \multicolumn{1}{c|}{ Keterangan } \\
\hline $\begin{array}{l}\text { Brand } \\
\text { Communication }\end{array}$ & - & - \\
\hline Brand Image & 0.083 & Sangat Rendah \\
\hline
\end{tabular}




\begin{tabular}{|l|l|l|}
\hline Brand Trust & 0.013 & Sangat Rendah \\
\hline Brand Loyalty & 0.147 & Sangat Rendah \\
\hline \multicolumn{3}{|c}{ Sumber: olahan SPSS }
\end{tabular}

Dari tabel diketahui variabel penggunaan brand communication mempengaruhi variabel brand image dengan nilai $\mathrm{R}$ square sebesar 0,083 atau 8,3\% yang artinya besar pengaruh sangat rendah, dimana sisa nilai tersebut $91,7 \%$ merupakan faktor lain yang mempengaruhi brand communication Partai Amanat Nasional (PAN). Sedangkan pengaruh brand communication dan brand image terhadap brand trust adalah 0,013 atau $1,3 \%$, dimana $98,7 \%$ dipengaruhi faktor lain. Terakhir, brand trust mempengaruhi brand loyalty dengan sangat rendah yaitu 14,7\% dimana $85,3 \%$ dipengaruhi faktor lainnya.

Selanjutnya peneliti menguji masingmasing hipotesis, dimana hipotesis akan diterima jika Sig $<0,05$.

Tabel 7. Uji Hipotesis Antar Variabel

\begin{tabular}{|l|l|l|}
\hline Variabel & Sig & Keterangan \\
\hline $\begin{array}{l}\text { H1: Brand } \\
\text { Communication }-> \\
\text { Brand Image }\end{array}$ & 0.545 & H1 ditolak \\
\hline $\begin{array}{l}\text { H2: Brand } \\
\text { Communication -> } \\
\text { Brand Trust }\end{array}$ & 0.121 & H2 ditolak \\
\hline $\begin{array}{l}\text { H3: Brand Image - } \\
>\text { Brand Trust }\end{array}$ & 0.547 & H3 ditolak \\
\hline $\begin{array}{l}\text { H4: Brand Trust }-> \\
\text { Brand Loyalty }\end{array}$ & 0.036 & H4 diterima \\
\hline
\end{tabular}

Dari tabel di atas, dapat diketahui $\mathrm{H} 1, \mathrm{H} 2$, H3 ditolak karena nilai masing-masing signya $>0,05$, yang artinya tidak ada pengaruh brand communication terhadap brand image, dan brand trust dan tidak ada pengaruh brand image terhadap brand trust Partai Amanat Nasional (PAN). Sedangkan $\mathrm{H} 4$ diterima, karena nilai sig $<0,05$, yang artinya terdapat pengaruh brand trust terhadap brand loyalty.

Brand communication disini berarti mengekspos tentang Partai Amanat Nasioanl (PAN) pada masyarakat dimana efeknya dapat dimaksimalkan untuk mengingatkan kesadaran mereka mengenai program yang dimiliki oleh PAN, sehingga pada saat Pemilu masyarakat memilih kader dari PAN diantara pesaing partai politik lainnya. Dengan adanya komunikasi merek oleh PAN seharusnya memberikan image yang positif terhadap partai tersebut di mata masyarakat. Namun ternyata, komunikasi merek pada PAN tidak berpengaruh terhadap brand image, hal ini dapat dikarenakan program-program yang dikomunikasikan partai luas, partai politik saat ini bukan sekedar brand partai tetapi juga dilihat dari kadernya. Oleh karena itu, faktor lain dalam konteks personal branding tokoh politik menjadi hal yang penting untuk membangun citra dan identitas partai politik di mata khalayak. Penelitian sebelumnya juga hanya berfokus pada marketing, sedangkan penelitian ini mengacu pada politik dimana konteksnya berbeda.

Brand communication tidak berpengaruh terhadap brand trust dimana seharusnya komunikasi yang disampaikan harus memperhatikan beberapa hal seperti isi pesan, pesan yang terstruktur, bagaimana menyampaikannya, dan siapa yang menyampaikan pesan. Hal ini mungkin menjadi faktor yang membuat komunikasi merek tidak berjalan dengan efektif sehingga tidak mempengaruhi kepercayaan masyarakat terhadap partai dalam mengkomunikasikan programnya. Penelitian terdahulu mengenai brand communication terhadap brand trust dengan konteks brandnya adalah Partai Politik Gerindra menjadikan brand trust sebagai variabel mediasi, sehingga komunikasi yang diciptakan Partai Gerindra dimediasi oleh kepercayaan untuk menciptakan loyalty bagi masyarakat untuk tetap memilih Partai Gerindra pada Pemilu berikutnya. Hal ini mungkin menjadi salah satu faktor yang menyebabkan tidak adanya pengaruh brand communication terhadap brand trust dalam konteks Partai Amanat Nasional (PAN).

Begitu pula dengan brand image terhadap brand trust, dimana ternyata dalam penelitian ini citra positif suatu partai belum tentu memberikan rasa percaya masyarakat terhadap partai politik tertentu. Hal ini dikarenakan PAN sebagai parpol yang memiliki program serta visi dan misi yang positif di masyarakat tetapi belum tentu membuat mereka merasa program yang dijalankan akan dijalankan sesuai dengan amanah.

Hipotesis terakhir diterima, yaitu adanya pengaruh brand trust terhadap brand loyalty. Ketika seseorang sudah memberikan kepercayaan terhadap suatu partai politik tertentu, maka ia sudah menjamin program yang diberikan oleh partai tersebut yang terbaik untuk diberikan pada masyarakat, sehingga seseorang akan konsisten untuk memilih partai yang sama di kemudian hari pada saat pemilihan berlangsung. Brand trust merupakan salah satu elemen yang paling signifikan jika berkaitan dengan branding pada pemasaran, karena kepercayaan merupakan kunci dari membangun hubungan dengan suatu merek. Kepercayaan terhadap partai politik PAN dapat diciptakan dari pengalaman dan interaksi masyarakat dari wakti ke wakti. Tingkat kepercayaan yang tinggi memungkinkan pemilih untuk mengurangi risiko dan menimbulkan adanya pengulangan dalam penggunaan merek (konteks ini berarti memilih PAN kembali dalam pemilu selanjutnya, yang berarti adanya loyalitas). Dengan adanya manfaat yang sudah dirasakan oleh pemilih, maka pemiih akan konsisten dengan pilihan partai politiknya (Kwan Soo Shin, Amenuvor, Basilisco, \& Owusu-Antwi, 2019). 


\section{KESIMPULAN}

Penelitian ini mencari adanya kaitan konsep brand communication, brand image, brand trust, dan brand loyalty dengan menggunakan metode survei sehingga menunjukkan adanya pengaruh yang signifikan antara variabel. Dari penelitian yang dilakukan, dapat disimpulkan bahwa brand communication tidak memiliki pengaruh terhadap brand image dan brand trust, hal ini dapat dikarenakan program-program yang dikomunikasikan partai luas, partai politik saat ini bukan sekedar brand partai tetapi juga dilihat dari kadernya komunikasi yang disampaikan harus memperhatikan beberapa hal seperti isi pesan, pesan yang terstruktur, bagaimana menyampaikannya, dan siapa yang menyampaikan pesan. Brand image yang positif juga belum tentu berpengaruh terhadap brand trust, dimana partai politik yang memiliki citra serta kinerja yang baik belum tentu membuat pemilih percaya akan program-program yang disampaikan. Namun, untuk kepercayaan pada partai politik, brand trust memiliki pengaruh terhadap brand loyalty, hal ini dipastikan karena kepercayaan terhadap partai politik PAN membuat pemilih untuk terus konsisten dengan pilihan partai di pemilihan selanjutnya.

Secara teoritis, penelitian dapat merekomendasikan teori political marketing lewat elemen brand communication, brand image, brand trust, dan brand loyalty pada partai politik yang dapat mempengaruhi pilihan pemilih pada Pemilu di Indonesia. Secara praktis, penelitian dapat menjadi pertimbangan pihak partai politik untuk lebih memperhatikan elemen-elemen pemasaran politik lainnya sehingga tujuannya untuk menarik pemilih, mempertahankan loyalitas pemilihnya tercapai. Keterbatasan dalam penelitian ini adalah tidak membandingkan bagaimana komunikasi partai politik seperti lewat media sosial, iklan, atau media komunikasi lainnya agar mengetahui channel komunikasi mana yang paling efektif dalam mempengaruhi elemen merek lainnya. Penelitian menunjukkan besar pengaruh yang rendah, oleh karena itu perlu diteliti lagi faktor yang mempengaruhi brand image, brand trust, dan brand loyalty patai politik seperti citra politisi, political branding, afiliasi partai politik, dan hal-hal lain yang dapat bertindak sebagai variabel independen.

\section{REFERENSI}

Abdelbaset M. Alkhawaldeh, Bt, S., \& Halim, F. bin. (2016a). An Empirical Study in Voting Behavior and Political Brand. International Business Management, 18(10), 4365-4372.

Abdelbaset M. Alkhawaldeh, Bt, S., \& Halim, M. S. bin. (2016b). Linkages between Political Brand Image, Affective Commitment and Electors
Loyalty: The Moderating Influence of Reference Group. International Journal of Business and Commerce, 5(04), 18-36.

Arenggoasih, W. (2017). PENGARUH BRAND COMMUNICATION, SERVICE QUALITY DAN BRAND PERSONALITY ANGGOTA DEWAN TERPILIH MELALUI BRAND TRUST TERHADAP BRAND LOYALTY PEMILIH (Studi Partai Politik Gerindra). Interaksi: Jurnal Ilmu Komunikasi, 5(2), 123. https://doi.org/10.14710/interaksi.5.2.123-135

Arif, S., Bhatti, A., Mariam, \& Sadiq, M. U. (2018). Impact of Social media brand communication on Brand Knowledge: Mediating role of Brand Image \& Brand Awareness Application of CBBE model theory of Keller. Journal of Management Info, 4(4), 12-18. https://doi.org/10.31580/jmi.v15i1.72

Darmawan, E., \& Septiana, A. (2019). Analisis Fungsi Partai Politik Pada Pilkada Musi Banyuasin 2017 (Studi Terhadap Partai Politik Pengusung Pasangan Dodi Reza Dan Beni Hernedi). Jurnal Studi Sosial Dan Politik, 3(1), 28-41.

Halim, R. E. (2011). The Effect of the Relationship of Brand Trust and Brand Affect on Brand Performance: An Analysis from Brand Loyalty Perspective (A Case of Instant Coffee Product in Indonesia). SSRN Electronic Journal, (January 2006). https://doi.org/10.2139/ssrn.925169

Kotler, P., Saunders, J., Armstrong, G., \& Wong, V. (1999). Principles Of Marketing (Second Eur). Milan: Prentice Hall Erurope.

Kwan Soo Shin, S., Amenuvor, F. E., Basilisco, R., \& Owusu-Antwi, K. (2019). Brand Trust and Brand Loyalty: A Moderation and Mediation Perspective. Current Journal of Applied Science and Technology, (November), 1-17. https://doi.org/10.9734/cjast/2019/v38i430376

Neuman, L. (2014). Social Research Methods; Qualitative and Quantitative Approaches Seventh Edition. Pearson. London: Pearson Education. https://doi.org/10.2307/3211488

Taherdoost, H. (2018). Sampling Methods in Research Methodology; How to Choose a Sampling Technique for Research. SSRN Electronic Journal, (September). https://doi.org/10.2139/ssrn.3205035

Zehir, C., Şahin, A., Kitapçi, H., \& Özçahin, M. (2011). The effects of brand communication and service quality in building brand loyalty through brand trust; the empirical research on global brands. Procedia - Social and Behavioral Sciences, 24(December), 12181231. https://doi.org/10.1016/j.sbspro.2011.09.142 
